\title{
Synthesis and characterization of triazenes derived from sulfonamides
}

\author{
Seda Ünsalan'1, Pelin Çıkla1, Ş. Güniz Küçükgüzel1, Sevim Rollas', Fikrettin Şahin², \\ Ömer Faruk Bayrak²
}

\begin{abstract}
A series of novel triazene derivatives 1-3, 1a-3a were synthesized by the coupling of diazonium salts of amines (sulfaguanidine, sulfapyridine, sulfamethoxazole) with $\mathrm{N}$-methylaniline / p-nitroaniline in acidic media. The structures of the synthesized compounds were confirmed by the spectral data (UV, IR, ${ }^{1} \mathrm{H}-\mathrm{NMR}, \mathrm{APCI}-\mathrm{MS}$ ) and elemental analysis. The effects of all the compounds on A 549 and L 929 cell lines growth were investigated. The cytotoxic and antitumor activities of these compounds have not been in vitro aganist A 549 and L 929 cell lines.
\end{abstract}

KEY WORDS: Triazene, sulfonamide, prontosil, azo reduction.

\section{INTRODUCTION}

Prontosil 4-[(2,4-diaminophenyl)azo]benzenesulfonamide (Figure 1), the first commercially available antibacterial antibiotic, was developed by a research team at the Bayer Laboratories of the IG Farben conglomerate in Germany.

The conversion of prontosil to sulfonamide is the first known examples on prodrug activation. This reaction occurs with the aid of azo reductase enzymes by the large intestinal microbiota. The reaction takes place in two steps, the formation of the hydrazo compound, followed by the reductive cleavage of the nitrogen bond (Figure 2).

The sulfonamide derivatives have attracted considerable pharmaceutical interest due to antibac-

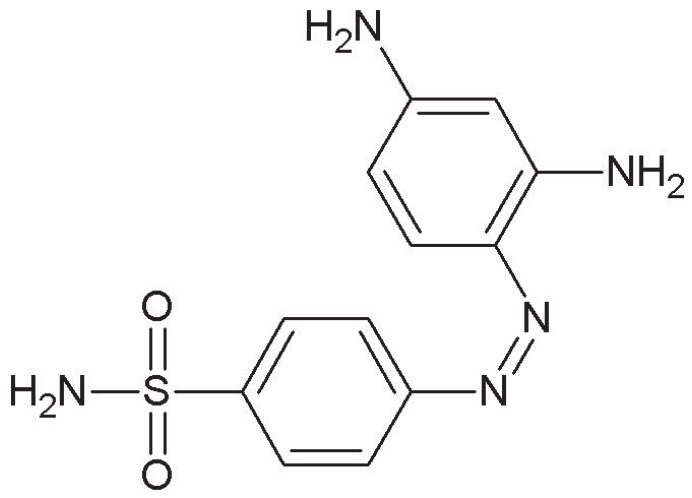

FIGURE 1. Prontosil terial, anticarbonic anhydrase, diuretic, hypoglycemic, antithyroid and protease inhibitory activity (1-6) In recent years, the novel sulfonamide derivatives have been reported to show potent inhibition of growth against several leukemia, non-small cell lung, ovarian, melanoma, colon, renal, prostate and breast cancer cell line (7)

A lot of antitumor drugs possess a limited bioavailability due to low chemical stability limited oral absorption or rapid metabolism (8). Because of these disadvantages, several prodrug models that can be activated into antitumor drugs have been designed. An important aspect of prodrug design is the need for converting rapidly to the active therapeutic agent in vivo. Some triazene derivatives provide a potential prodrug system for anticancer activity (9). On the other hand, some researchers synthesize a range of triazene derivatives and investigate as a prodrug candidates for melanocyte-directed enzyme prodrug therapy (10).

One of the most prevalent usage of the triazenes is in the development of antitumor molecules. Chemotherapeutic agents of the triazene class have been used in the clinical management of many tumors including brain, leukemias, melanomas $(11,12)$; metastatic malignant melanoma, cancer of colon and Hodgkin's disease such as dacarbazine $(12,13)$ Dacarbazine; [5-(3,3-dimethyl-1-triazeno)imidazole-4-carboxamide] which is used in the treatment of malignant melanoma
AFFILIATIONS

${ }^{1} \mathrm{MÜ.}$. Eczacılık Fakültesi, Farmasötik Kimya AD., İstanbul, Türkiye

2Yeditepe Üniversitesi, Mühendislik ve Mimarlık Fakiltesi, Genetik ve Biyomühendislik Bölümü, İstanbul, Türkiye

CORRESPONDENCE

Sevim Rollas

E-mail:

sevim@sevimrollas.com

Received:

05.11.2010

Revision:

24.11.2010

Accepted:

08.12.2010 


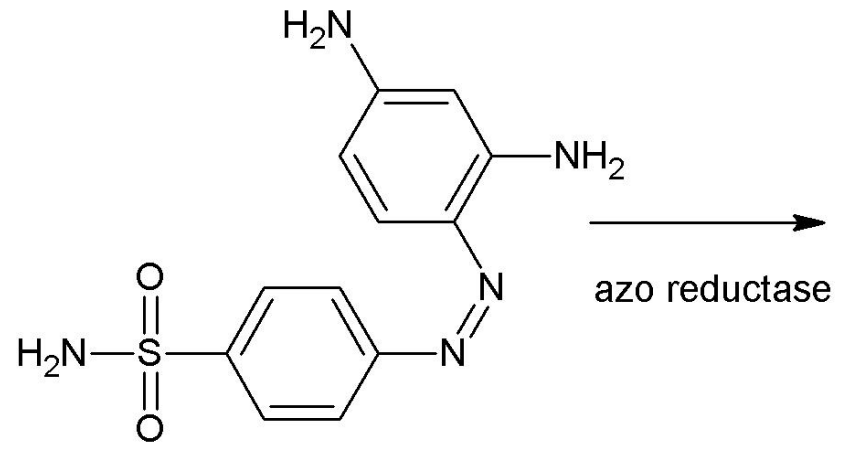

FIGURE 2. Azo reduction of prontosil

is the first generation of arylalkyltriazenes. A number of cyclic arylmonoalkyltriazenes, 8-carbamoyl-3-alkylimidazo[5,1- $d$ ]1,2,3,5-tetrazin-4(3H)-one, have been designed as potential therapeutic alternatives to dacarbazine (14). This antitumor activity observed in several murine tumor models has been reported to be comparable with or superior to that of dacarbazine $(13,15-17)$. Temozolomide, which is a triazene prodrug, was shown to be effective for the treatment of certain central nervous system neoplasms and in vitro aganist lung cancer as well as aganist brain metastasis from non-small lung cancer (18). The researches for more effective anticancer agents has focused to a large extent on the design of molecules capable of recognizing and binding to target DNA base sequences. Structural and biophysical studies of the antitryponosomal agent, Berenil [bis(4-amidinophenyl)-1,3-triazene], have shown that the molecule binds in a DNA duplex minor groove with a preference for Adenine/Timine-rich base tracts (19-21).

In our department, a series of triazenes derived from 5-(4-aminophenyl)-2,4-dihydro-4-substituted-3H-1,2,4-triazole-3-thiones have been synthesized for in vitro anticancer properties against three cell lines (22); 1-[(4-Carboxy)phenyl]3-[4(4-allyl-2,4-dihydro-3H-1,2,4-triazole-3-thioxo-5-yl) phenyl]-3H-triazene has been showed only the marked effects on breast cancer cell lines (Figure 3). Some compounds that pass the criteria for activity in this assay have been scheduled automatically for evaluation against the full panel of 60 human tumour cell lines and showed variable antitumor activity

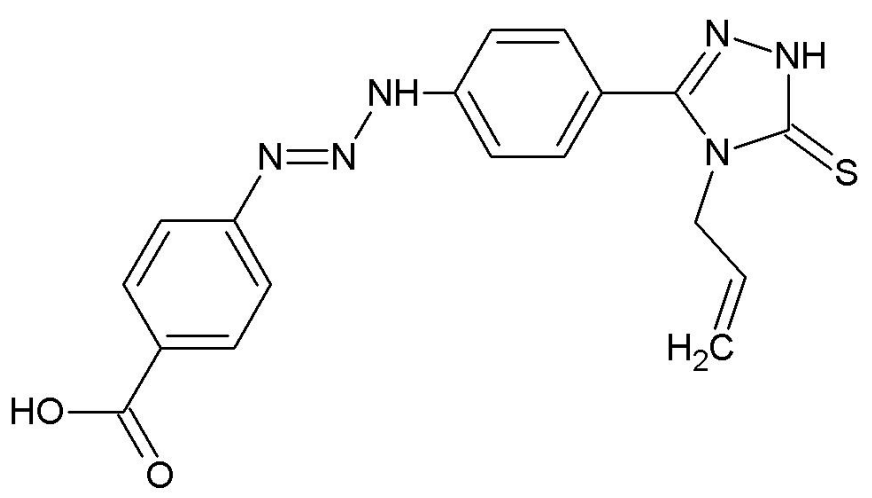

FIGURE 3. 1-[(4-Carboxy)phenyl]-3-[4(4-allyl-2,4-dihydro-3H-1,2,4-triazole-3thioxo-5-yl)phenyl]-3H-triazene against most of the tested sub-panel tumor cell lines. In our other previous study, we reported that the synthesis of some novel triazenes and diazenes derived from $N$-methylaniline and to evaluate preliminary antitumor activity of these compounds in vitro against Huh-7-liver cancer cell (23).

Mathews et al. have been shown that 1,3-triazeno functional group such as 1,3-diphenyl-1-triazene (DPT) ) is metabolized by the pathway proposed in Figure 4 . In this scheme, DPT is reduced by $\mathrm{P} 450$ reductase to form phenyl diazenyl radical and aniline that decomposes to form benzene and nitrogen gas (24). Antitumor activity of DPT attributed both to the aryldiazonium cations, formed by hydrolysis of an aryldimethyltriazene and to the methylation of bionucleophiles by the carbocations generated by solvolysis of arylmonomethyltriazenes.

Overexpression of epidermal growth factor receptor (EGFR) is observed in many human breast cancers. Recently, "combitargeting concept" is termed as a novel tumor-targeting strategy by researchers in antitumor drug development. SMA41 (25); a 3-methyltriazene termed "combi-molecules" have been reported to possess EGFR/DNA targeting properties induced potent antiproliferative activity. Due to its poor hydrosolubility novel triazene compounds designed by Brahimi et al (26).

These observations led us to directed "combi-targeting concept" is termed as a novel tumor-targeting strategy. In this study, we designed novel triazene drugs due to conversation of methylating agent and sulfanilamide, is defined antitumor activitiy, recently.

\section{RESULTS AND DISCUSSION}

\section{Chemistry}

A synthetic route for the target triazenes 1-3, 1a-3a is outlined in the Figure 6. The diazonium salts derived from containing an aromatic primary amine group (sulfaguanidine, sulfapyridine, sulfamethoxazole) were coupled with $N$-methylaniline and 4-nitroaniline resulting in the formation of triazenes. Aromatic primary amines have been treated with nitrite ion under hydrochloric acide $(22,23,27)$ and hydrochloric acide: gl.acetic acid $(1 / 1, h / h)$ to form a diazonium salts, which are used to provide the desired triazene (28). In this study, we used hydrochloric acide: glacetic acid $(1 / 1, \mathrm{~h} / \mathrm{h})$ for acidic media to form triazene compounds. 


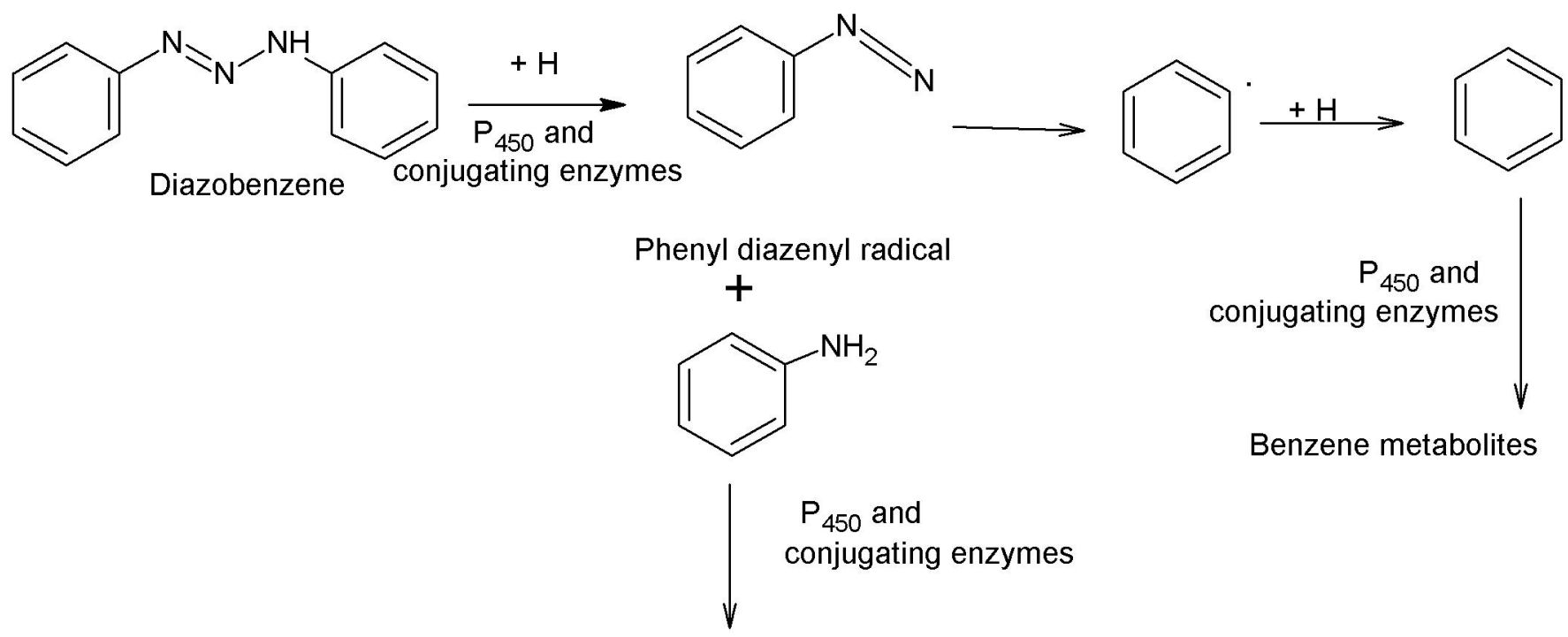

Aniline metabolites

FIGURE 4. Proposed pathway for DPT metabolism

The target compounds were prepared by using the reaction sequence in Figure 6. We synthesized a series of novel triazene derivatives, in which diazonium salts of aromatic primary amines were treated with $\mathrm{N}$-methyl aniline and p-nitroaniline according to literature (28). The structures of six new synthe-<smiles>CN/N=N/c1ccc2ncnc(Nc3cccc(C)c3)c2c1</smiles>

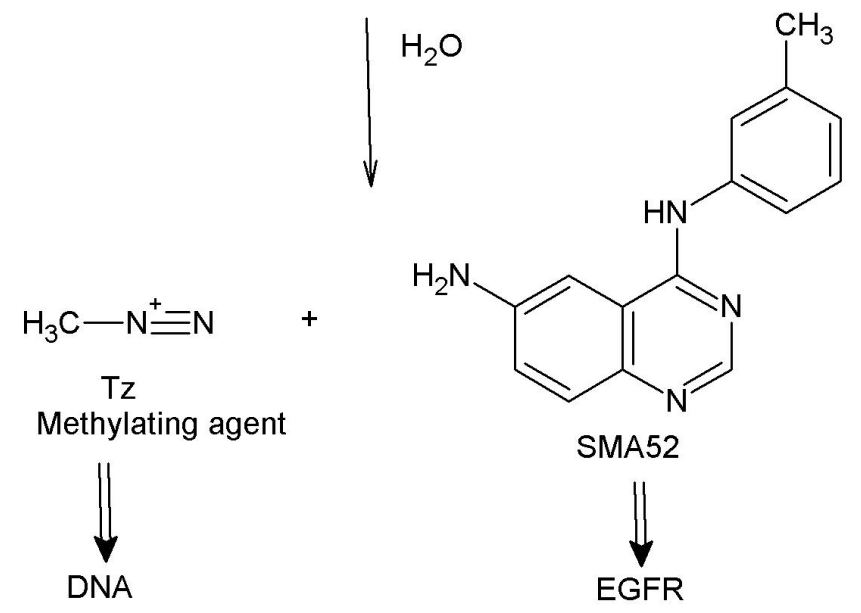

FIGURE 5. SMA41 sized compounds were confirmed by elemental analysis $(C, H$, $\mathrm{N}, \mathrm{S}), \mathrm{UV}, \mathrm{IR},{ }^{1} \mathrm{H}-\mathrm{NMR}$ and APCI-MS spectra. Analysis data of all the synthesized compounds were in full agreement with the suggested molecular structures. The chemical shifts of $\mathrm{N}-\mathrm{CH}_{3}$ protons of 1-3 were observed 2.09 ppm in ${ }^{1} \mathrm{H}-\mathrm{NMR}$ spectra (2933). The signals of triazene compounds (1a-3a) arising from $\mathrm{NH}-$ at 13.27-13.39 ppm were observed. This finding also supported the idea that the structures of these compounds should be given in triazene form. The signals of triazene compund, $2 \mathrm{a}$ arising from $\mathrm{N}-\mathrm{H}$ was not observed. This proton was exchangable with DMSO- $d_{6}$. The remaining protons were also observed at the expected regions. The signals of $\mathrm{N}$-methylaniline/4-nitroaniline and aromatic primary amines $\left(\mathrm{Ar}-\mathrm{NH}_{2}\right)$ arising from the asym. and sym. streching bands were not observed. Instead of these bands, The IR spectra of triazene compounds showed typical bands corresponding to the triazene group $(-N=N-N)$ at 1334-1392 $\mathrm{cm}^{-1}(32,34-36)$. In addition, triazene compounds were also characterised by their UV absorption. Maximum absorption bands of triazenes were detected at 352-389 $\mathrm{nm}(20,37-$ 40). The APCI-MS spectra of 1-3 and 1a-3a showed molecular ion $\left[\mathrm{M}^{+}+1\right]$ which confirmed its molecular weight. These findings also supported the idea that the structures of these compounds should be given in triazene form.

\section{BIOLOGICAL ACTIVITY}

\section{Antitumor and Cytotoxic Activity}

Cytotoxic and anticancer effects of synthesized compounds at four different concentrations tested. The CellTiter 96 Aqueous ONE Solution (Promega, Madison, WI) was used to evaluate cellular viability utilizing reduction of 3-(4,5-dimethylthiazol2-yl)-5-(3-carboxymethoxyphenyl)-2-(4-sulfophenyl)-2Htetrazolium (MTS) cell culture and viability assay. A 549 and L 929 cell line were used to test both anticancer effects and cytotoxicity. Cell viability was analyzed using the MTS assay. The cytotoxic and antitumor activity of triazenes from sulfonamides on A549 lung cell growth showed not inhibititon. Only 

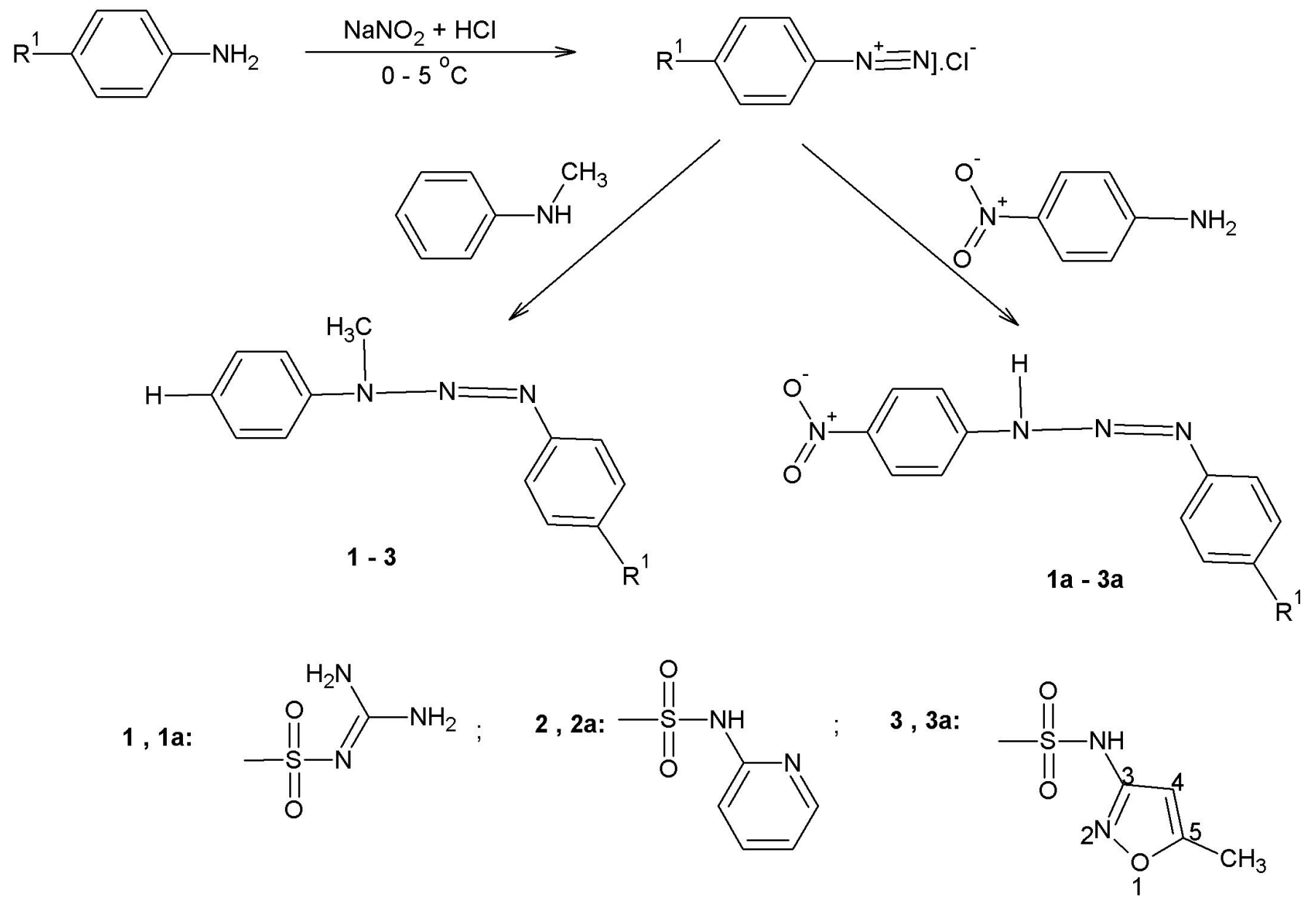

FIGURE 6. The synthesis pathway of the studied compounds

compound 3a had a cytotoxic effect on cancer cells when used at a concertration of $10 \mu \mathrm{M}$ at the first day. After the first day the effect did not continue probably because the cancer cells metabolized the chemical.

The lipophilicity of the compounds is well known to play an important role in the penetration of these compounds into cells. The compounds of lipophilicity results were calculated using ALOGPS 2.1 software. The calculated of values demonstrated that increasing/descrasing the lipophilic character of compounds the activity. Because of the lack of antitumor activity compounds through arildiazonyum salts (Figure 4) can be considered.

\section{EXPERIMENTAL}

\section{Chemistry}

Melting points were determined on a Schmelzpunktbestimmer SMP II and are uncorrected. The UV spectra was measured with a Schimadzu UV-2100S. The IR spectra were recorded on Schimadzu FTIR-8400 S. ${ }^{1} \mathrm{H}-\mathrm{NMR}$ spectra in dimethylsulfoxide- $\mathrm{d}_{6}\left(\right.$ DMSO- $\left.\mathrm{d}_{6}\right)$ were obtained on a Bruker AvanceDPX 400 spectrometer. Tetramethylsilane (TMS) was used as an internal standard and all chemical shift values were recorded as $\delta(\mathrm{ppm})$ values. Mass spectra of synthesized compounds were performed using Agilent 1100 MSD LC-MS. The elemental analysis for $\mathrm{C}, \mathrm{H}, \mathrm{N}, \mathrm{S}$ was obtained on a Leco CHNS-932 instrument. ( ${ }^{1} \mathrm{H}-\mathrm{NMR}, \mathrm{APCI}-\mathrm{MS}$ and Elemental analysis were provided by the Scientific and Technical Research Council of Turkey Instrumental Analysis Laboratories, Ankara-Turkey). All chemicals used in this study were supplied from Aldrich Chemical Co., Merck and Sigma.

\section{General procedure for the preperation of triazenes} (1-3, 1a-3a)

To a magnetically stirred cold solution (ice-bath $0-5^{\circ} \mathrm{C}$ ) of these aromatic primary amines $(3 \mathrm{mmol})$ in $6 \mathrm{~N}$ aqueous hydrochloric acid/acetic acid $(1: 1, \mathrm{~h} / \mathrm{h})$, acetone $(1 \mathrm{ml})$ and a ice-cold solution of sodium nitrite $(0.21 \mathrm{~g}, 3 \mathrm{mmol})$ in water $(1 \mathrm{ml})$ was added dropwise. Stirring was continued at $0-5^{\circ} \mathrm{C}$ and then the reaction mixture was treated at the same temperature with a $40 \%$ aqueous $N$-methylaniline solution $(6 \mathrm{mmol})$ for $1-3$ and $\mathrm{p}$ nitroaniline ( $3 \mathrm{mmol}$ ) for 1a-3a. The reaction mixture was waited overnight at room temperature in dark. The precipitated solid that seperated was washed with cold water, filtered off and then crystallized from ethanol.

$N$-(Diaminomethylene)-4-(3-methyl-3-phenyltriaz-1-ene-1-yl) benzenesulfonamide (1). Brown (ethanol), yield: 60\%, mp 229 ${ }^{\circ} \mathrm{C}$ : UV $\lambda_{\max }(\mathrm{EtOH})(\mathrm{nm}): 352,238,207$. IR $\bar{v}_{\max .}\left(\mathrm{cm}^{-1}\right): 3444$, 
3325, 3143, 2939, 1639, 1593, 1539, 1500, 1458, 1334, 1164, 825, 752. ${ }^{1} \mathrm{H}-\mathrm{NMR}\left(400 \mathrm{MHz}, \mathrm{DMSO}-\mathrm{d}_{6}\right) \mathrm{d}(\mathrm{ppm}): 2.09$ (s, 3H, $\left.\mathrm{N}-\mathrm{CH}_{3}\right), 6.41-7.03$ (b.s., $\left.4 \mathrm{H}, \mathrm{N}=\mathrm{C}\left(-\mathrm{NH}_{2}\right)_{2}\right), 7.19-8.37$ (m, 9H, ArH). APCI-MS (m/z, \%): 333 (100) [M+1] ${ }^{+}, 305$ (31.4) , 215 (4.8), 199 (24.5), 182 (17.9); Anal. $\mathrm{C}_{14} \mathrm{H}_{16} \mathrm{~N}_{6} \mathrm{O}_{2} \mathrm{~S}$ calc. for: $\mathrm{C}, 50.59 ; \mathrm{H}$, 4.85; N, 25.28; S, 9.65. Found: C, 51.20; H, 4.73; N, 24.98; S,9.53 $\%$. Log P : $2.18 \pm 0.50$.

\section{$\mathrm{N}$-(Diaminomethylene)-4-[3-(4-nitrophenyl)triaz-1-ene-1-yl]} benzenesulfonamide (1a)

Yellow (ethanol), yield: $85 \%, \operatorname{mp} 238^{\circ} \mathrm{C}$ : UV $\lambda_{\max }(\mathrm{EtOH})(\mathrm{nm})$ : 380, 248, 199. IR $\bar{v}_{\max . .}\left(\mathrm{cm}^{-1}\right): 3479,3367,3290,1627,1601,1530$, 1508, 1481, 1334, 1172, 829. ${ }^{1} \mathrm{H}-\mathrm{NMR}\left(400 \mathrm{MHz}, \mathrm{DMSO}_{6}\right) \mathrm{d}$ (ppm): 6.60 (d, 2H, m-nitro, $J=9 \mathrm{~Hz}), 6.73\left(\mathrm{~s}, 4 \mathrm{H}, \mathrm{N}=\mathrm{C}\left(\mathrm{NH}_{2}\right)_{2}\right)$, $7.79(\mathrm{~d}, 2 \mathrm{H}$, o-triazene, $J=9 \mathrm{~Hz}), 7.95(\mathrm{~d}, 2 \mathrm{H}$, o-nitro, $J=9 \mathrm{~Hz})$, $8.28(\mathrm{~d}, 2 \mathrm{H}, \mathrm{m}$-triazene, $\mathrm{J}=9 \mathrm{~Hz}), 13.27(\mathrm{~s}, 1 \mathrm{H}$, triazene $\mathrm{NH})$. $\operatorname{APCI}-\mathrm{MS}(\mathrm{m} / \mathrm{z}, \%): 364[\mathrm{M}+1]^{+}$(28.1), 336 (31.2), 215 (100), 200 (59.9). Anal. $\mathrm{C}_{13} \mathrm{H}_{13} \mathrm{~N}_{7} \mathrm{O}_{4} \mathrm{~S}$ calc. for: $\mathrm{C}, 42.97 ; \mathrm{H}, 3.61 ; \mathrm{N}, 26.98$; S, 8.82. Found: C, 43.36; H, 3.92; N, 27.42; S, 9.18 \%. Log P : 2.21 \pm 0.75 .

4-(3-Methyl-3-phenyltriaz-1-ene-1-yl)-N-pyridine-2-ylbenzenesulfonamide (2)

Orange (ethanol), yield: $56 \%, \mathrm{mp} 204-206{ }^{\circ} \mathrm{C}$ : UV $\lambda_{\max }(\mathrm{EtOH})$ (nm): 355, 239, 206. IR $\bar{v}_{\max .}\left(\mathrm{cm}^{-1}\right): 3217,3028,2931,2812,1631$, 1596, 1531, 1500, 1461, 1361, 1155, 844, 767. ${ }^{1} \mathrm{H}-\mathrm{NMR}(400 \mathrm{MHz}$, DMSO-d ${ }_{6}$ ) d (ppm): 2,09 (s, 3H, N-CH $\left.{ }_{3}\right), 6.86-8.02$ (m, 9H, Ar$\mathrm{H}), 11.74-12.41$ (b.s., $\left.1 \mathrm{H}, \mathrm{SO}_{2} \mathrm{NH}\right)$. APCI-MS $(\mathrm{m} / \mathrm{z}, \%): 368$ $[\mathrm{M}+1]^{+}(100), 340$ (47). Anal. $\mathrm{C}_{18} \mathrm{H}_{17} \mathrm{~N}_{5} \mathrm{O}_{2}$ S calc.for: C, 58.84; $\mathrm{H}$, $4.66 ; \mathrm{N}, 19.06 ; \mathrm{S}, 8.73$. Found: C, 59.61; H, 4.51; N, 18.96; S, $8.56 \%$. $\log P: 3.56 \pm 0.50$.

4-[(3-(4-Nitrophenyl)triaz-1-ene-1-yl]-N-pyridine-2-yl-

benzenesulfonamide (2a)

Brown (ethanol), yield: $59 \%$; $\mathrm{mp} 213^{\circ} \mathrm{C}$ : UV $\lambda_{\max }(\mathrm{EtOH})(\mathrm{nm})$ : $377,243,202$. IR $\bar{v}_{\text {max. }}\left(\mathrm{cm}^{-1}\right): 3217,3078,1631,1596,1504,1473$, 1446, 1392, 840. ${ }^{1} \mathrm{H}-\mathrm{NMR}\left(400 \mathrm{MHz}, \mathrm{DMSO}_{6}\right.$ ) d (ppm): 6,586,62 (d, 4H, ArH), 6,73 (s, 4H, CH pyridine), 7.93-7.96 ( d, 4H, Ar-H). APCI-MS (m/z, \%): $399[\mathrm{M}+1]^{+}$(4.8), 371 (23.3), 250 (100), 235 (84.6). Anal. $\mathrm{C}_{17} \mathrm{H}_{14} \mathrm{~N}_{6} \mathrm{O}_{4} \mathrm{~S}$ calc. for: $\mathrm{C}, 51.25 ; \mathrm{H}, 3.54$; N, 21.09; S, 8.05. Found: C, 50.94; H, 3.45; N, 20.76; S, 7.92\%. $\log P: 3.52 \pm 0.75$.

$\mathrm{N}$-(5-Methylisoxazole-3-yl)-4-(3-methyl-3-phenyltriaz-1-ene1-yl)benzenesulfonamide (3). Orange (ethanol), yield: $64 \%, \mathrm{mp}$ 183-184 ${ }^{\circ} \mathrm{C}$ : UV $\lambda_{\max }(\mathrm{EtOH})(\mathrm{nm}): 355,239,208$. IR $\bar{v}_{\max .}\left(\mathrm{cm}^{-1}\right)$ : 3310, 3147, 2940, 2831, 1620, 1593, 1500, 1469, 1431, 1338, 1157, 844, 756. ${ }^{1} \mathrm{H}-\mathrm{NMR}\left(400 \mathrm{MHz}, \mathrm{DMSO}_{6}\right.$ ) d (ppm): 2.09 (s, 3H, $\left.\mathrm{C}^{-} \mathrm{CH}_{3}\right), 2.30\left(\mathrm{~s}, 3 \mathrm{H}, \mathrm{N}-\mathrm{CH}_{3}\right), 6.17\left(\mathrm{~s}, 1 \mathrm{H}\right.$, isoxazole, $\left.\mathrm{C}_{4}-\mathrm{H}\right), 7.21-$ $7.90(\mathrm{~m}, 9 \mathrm{H}, \mathrm{Ar}-\mathrm{H}), 11.45$ (s, 1H, $\left.\mathrm{SO}_{2} \mathrm{NH}\right)$. APCI-MS (m/z, \%):
$372[\mathrm{M}+1]^{+}(100), 344$ (33.1). Anal. $\mathrm{C}_{17} \mathrm{H}_{17} \mathrm{~N}_{5} \mathrm{O}_{3} \mathrm{~S}$ calcd. for: $\mathrm{C}$, 54.97; H, 4.61; N, 18.86; S, 8.63. Found: C, 55.90; H, 4.69; N, $18.80 ; \mathrm{S}, 8.63 \%$. Log $\mathrm{P}: 3.58 \pm 0.46$.

$\mathrm{N}$-(5-Methylisoxazole-3-yl)-4-[3-(4-nitrophenyl)triaz-1-ene-1yl]benzenesulfonamide (3a)

Yellow (ethanol-water), yield: $63 \%$; mp: $188{ }^{\circ} \mathrm{C}$ : UV $\lambda_{\max }$ (EtOH) (nm): 389, 206; IR $\bar{v}_{\max }\left(\mathrm{cm}^{-1}\right): 3259,3050,2993,1596$, 1512, 1465, 1446, 1338, 1161, 845. ${ }^{1} \mathrm{H}-\mathrm{NMR}(400 \mathrm{MHz}, \mathrm{DMSO}-$ $\left.\mathrm{d}_{6}\right) \mathrm{d}(\mathrm{ppm}): 2.31\left(\mathrm{~s}, 3 \mathrm{H}, \mathrm{C}_{5}-\mathrm{CH}_{3}\right), 6.17\left(\mathrm{~s}, 1 \mathrm{H}\right.$, isoxazole, $\left.\mathrm{C}_{4}-\mathrm{H}\right)$, 7.90-8.33 (m, 8H, Ar-H), 11.46 (s, 1H, SO $2 \mathrm{NH}), 13.39$ (s,1H, triazene NH). APCI-MS (m/z, \%): $403[\mathrm{M}+1]^{+}(62.3), 375$ (100), 254 (91.6). Anal. $\mathrm{C}_{16} \mathrm{H}_{14} \mathrm{~N}_{6} \mathrm{O}_{5} \mathrm{~S}$ calcd. for: $\mathrm{C}$, 47.76; H, 3.51; N, 20.89; S, 7.97. Found: C, 48.52; H, 3.34; N, 20.45; S, 7.94\%. Log P : 3.54 \pm 0.40 .

\section{BIOLOGICAL METHODS}

\section{Antitumor and cytotoxic activity}

The synthesized compounds were tested for their anticancer activities and cytotoxicity properties. The CellTiter 96 Aqueous ONE Solution (Promega, Madison, WI) was used to evaluate cellular viability utilizing reduction of 3-(4,5-dimethylthiazol-2-yl)-5-(3-carboxymethoxyphenyl)-2-(4-sulfophenyl)-2Htetrazolium (MTS). A 549 and L 929 cell line were used to test both anticancer effects and cytotoxicity. Cells were routinely grown in a 75-mm flask in an environment containing $5 \% \mathrm{CO}_{2}$ and passed every 3 days. Cell viability was analyzed using the MTS assay. 5.000 Cells were plated in each well of a 96-well tissue culture plate. After 24 hours of growth the medium was replaced with fresh medium containing different concentration $(10 \mathrm{nM}, 100 \mathrm{nM}, 1 \mu \mathrm{M}$ and $10 \mu \mathrm{M})$ of chemicals, and the cells were grown for 4 days (41).

The MTS assay was performed according to the protocol provided by the Manufacturer. In short, $20 \mu \mathrm{L}$ of MTS solution was added to each well, and cells were incubated at $37^{\circ} \mathrm{C}$ for 1 to 3 hours. The absorbance (at $490 \mathrm{~nm}$ ) of each well was determined. Data are presented as a percentage of the values obtained from cells cultured under the same conditions in the absence of chemicals. For the time course study of chemicals' cytotoxicity, L 929 cells were treated with chemicals with the same dose used to detect anticancer activity. Cell viability was analyzed 1 to 4 days after the initiation of treatment, using the MTS assay.

Although all test compounds were dissolved in DMSO and the final concentration of DMSO was $0.1 \%$, the solvent showed no activity in these assays at the level that was used for screening. For comparison of the anticancer activity and cytotoxicity ob-

\section{Sülfonamitlerden türeyen triazenlerin sentezi ve karakterizasyonu}

ÖZET: Bir seri yeni triazen türevleri olan 1-3, 1a-3a bileşikleri, asidik ortamda aminlerin diazonyum tuzlarının (sülfoguanidin, sülfopiridin, sülfometoksazol) N-metil anilin/p-nitroanilin ile kenetlenmesi sonucunda sentezlenmiştir. Sentezlenen bu bileşiklerin yapıları, spektral bulgular (UV, IR, ${ }^{1} \mathrm{H}-\mathrm{NMR}$ ) ve elemental analiz ile aydınlatıImıştır. Tüm bileşiklerin, in vitro olarak A 549 ve L 929 hücre dizilerinin büyümesine etkileri araştırılmış, sitotoksik ve antitumor aktiviteleri bulunmamıştır.

ANAHTAR KELIMELER: Triazen, sülfonamit, prontosil, azo redüksiyon 
served with the test compounds, doxorubicin and taxol were selected as standard drugs.

\section{ACKNOWLEDGEMENT}

This study was supported by Scientific Research Project Commission of Marmara University (Project number: SAĞBGS-270306-0037).

\section{REFERENCES}

1. Scozzafava A, Supuran. CT. Carbonic anhydrase and matrix metalloproteinase inhibitors. Sulfonylated amino acid hydroxamates withMMP inhibitory properties act as efficient inhibitors of carbonic anhydrase isozymes I, II and IV, and N-hydroxy sulfonamides inhibit both these zinc enzymes. J Med Chem, 43: 3677-3687, 2000.

2. Wilkinson BL, Bornaghi LF, Wright, AD, Houston TTA, Poulsen A. Anti-mycobacterial activity of a bis-sulfonamide. Bioorg Med Chem Lett, 17: 1355-1357, 2007.

3. Güzel Ö, Temperini C, Innocenti A, Scozzafava A, Salman A, Supuran CT. Carbonic anhydrase inhibitors. Interaction of 2-(hydrazinocarbonyl)-3-phenyl-1H-indole5-sulfonamide with 12 mammalian isoforms: Kinetic and X-ray crystallographic studies. Bioorg Med Chem Lett, 18: 152- 158, 2008.

4. Kim J.S, Jung M, Ho Yoo K, Cho J, Hyun Ho C Synthesis and antibacterias activities of novel oxazolidinones having cyclic sulfonamides moities. Bioorg Med Chem Lett, 18: 5815-5818, 2008.

5. Crocetti L, Maresca A, Temperini C, Hall RA, Scozzafava A, Mühlschlegel FA, Supuran CT. A thiabendazole sulfonamide shows potent inhibitory activity against mammalian and nematode alpha-carbonic anhydrases. Bioorg Med Chem Lett, 19:1371-1375, 2009.

6. Ghorab MM, Ragab FA, Hamed MM. Design, synthesis and anticancer evaluation of novel tetrahydro-quinoline derivatives containig sulfonamide moiety. Eur J Med Chem, 44: 4211-4217, 2009.

7. Scozzafava A, Owa T, Mastrolorenzo A, Supuran CT. Anticancer and antiviral sulfonamide. Curr Med Chem, 10:925-953, 2003.

8. Rollas $S$, Küçükgüzel ŞG. Hydrazone, amide, carbamate, macromolecular and other prodrugs of doxorubicin. The Open Drug Deliv J, 2: 77-85, 2008.

9. Perry MJ, Carvolho E, Rosa E, Iley J. Towards an efficient prodrug of the alklating metabolite monomethyltriazene: synthesis and stability of N-acylamino acid derivatives of triazene. Eur J Med Chem, 44:1049-1056, 2008.

10. Perry MJ, Mendes E, Simplicio AL, Coelho A, Soares RV, Iley J, Moreira R, Francisco AP Dopamine and tyraminebased derivatives of triazenes: activation by tyrosinase and implications for prodrug design. Eur J Med Chem, 44: 3228-3234, 2009.

11. Smith RH Jr, Scudiero DA, Michejda CJ. 1,3-dialkyl-3acyltriazenes, a novel class of antineoplastic alkylating agents. J Med Chem, 33: 2579-2583, 1990.

12. Sanada $M$, Takagi $Y$, Ito $R$, Sekiguchi $M$. Killing and mutogenic actions of dacarbazine, a chemotherapeutic alkylating agent, on human and mouse cells: effects of Mgmt and Mih1 mutations. DNA Repair, 3: 413-420, 2004.
13. Gescher A, Threadgill MD. The metabolism of triazene antitumor drugs. Pharmacol Ther, 32: 191-205, 1987.

14. Gibson NW, Erickson LC, Hickman JA. Effects of the antitumor agent 8-carbamoyl-3-(2-chloroethyl) imidazo[5,1-d]-1,2,3,5-tetrazin-4(3H)-one on the DNA of mouse L1210 cells. Cancer Res, 44: 1767-1771, 1984.

15. Cheng CC, Elslager EF,Werbel LM, Priebe SR, Leopold WR Pyrazole derivatives. 5. Synthesis and antineoplastic activity of 3-(2-chloroethyl)3,4-dihydro-4oxopyrazolo[5,1-d]-1,2,3,5-tetrazine-8-carboxamide and related compounds. J Med Chem, 29: 1455-1547, 1986.

16. Tsang LLH, Quarterman CP, Gescher A, Slack JA Comparison of the cytotoxicity in vitro of temozolomide and dacarbazine, prodrugs of 3-methyl-(triazen-1-yl)imidazole-4-carboxamide. Cancer Chemother Pharmacol, 27: 342-346, 1991.

17. Clark AS, Deans B, Stevens MFG, Tisdale MJ, Wheelhouse RT, Denny BJ, Hartley JA. Antitumor imidazotetrazines. 32. Synthesis of novel imidazoteteazines and related bicyclic heterocycles to probe the mode of action of the antitumor drug temozolomide. J Med Chem, 38: 1493-1504, 1995.

18. Kouroussis C, Vamvakas L, Vardakis N, Kotsakis A, Kalykaki A, Kalbakis K, Saridaki Z, Kentepozidis N, Giassas S, Georgoulias V. Continous administration of daily low-dose temozolomide in pretreated patients with advanced non-small cell lung cancer: a phase II study. Oncology, 76: 112-117, 2009.

19. McConnaughie AW, Jenkins TC. Novel acridine-triazenes as protype combilexins:synthesis, DNA binding and biological activity. J Med Chem, 38: 3488-3501, 1995.

20. Coates L, Ikpeazu EV, Chen $Y$, Valenzuela MS. Inhibition of DNA replication by berenil in plasmids containig poly(dA)poly(dT) sequences. Plasmid, 47: 120-128, 2002.

21. Burr SJ, Mselati A, Thomas EW. Photochemical DNA cleavage by a berenil analog. Tetrahedron Lett, 44: 73077309, 2003.

22. Unsalan $S$, Rollas $S$. Synthesis and primary cytotoxic evaluation of new diaryltriazenes. Indian J Chem Sec B, 46: 185-191, 2007.

23. Çıkla $P$, Rollas $S$. Synthesis of some new triazene and diazene derivatives and in vitro evaluation of preliminary antitumor activities. FABAD. J Pharm Sci, 32: 33-40, 2007.

24. Mathews JM, Costa KS Absorption, metabolism and disposition of 1,3-diphenyl-1-triazene in rats and mice after oral, i.v. and dermal administration. Drug Metab Dispos, 27: 1499-1504, 1999.

25. Matheson SL, McNamee JP, Wang $T$, Alaoui-Jamali MA, Jean-Claude BJ. The combi-targeting concept: dissection of the binary mechanism of action of the combi-triazene SMA41 in vitro and antitumor activity in vivo. J Pharm Exp Ther, 311: 1163-1170, 2004.

26. Brahimi F, Rachid $Z$, McNamee JP, Alaoui-Jamali MA, Tari AM, Jean-Claude BJ. Mechanism of action of a novel "combi-triazene" engineered to possess a polar functional group on the alkylating moiety: Evidence for enhancement of potency. Biochem Pharmacol, 70: 511-519, 2005.

27. Manolov I, Machullam HJ, monekov G. Synthesis, physicochemical characterization and preliminary pharmacological in vitro evaluation of two novel cytotoxic benzophenone-linked 3,3-dimethyltriazenes. Pharmazie, 61: 511-516, 2006. 
28. Daidone G, Raffa D, Maggio B, Raimondi MV, Plescia F, Schillaci D. Synthesis and antiproliferative activity of triazenoindazoles and triazenopyrazoles: a comparative study. Eur J Med Chem, 39: 219-224, 2004.

29. Vaughan $K$, Gamage Nicholas KUK, Singer RD, Roy M, Gibson NW. Triazene metabolism VI. 3-azidomethyl-3alkyl-1-aryltriazenes, a new class of anti-tumour triazene with potential pro-drug applications. Anti-Cancer Drug Design, 2: 279-287, 1987.

30. Carvalho E, Francisco AP, Iley J, Rosa E. Triazene drug metabolites. Part 17: synthesis and plasma hydrolysis of acyloxymethyl carbamate derivatives of antitumor triazenes. Bioorg Med Chem, 8: 1719-1725, 2000.

31. Pages $T$, Langlois $B R$, Bars DL, Landais P. Fluorination of aromatic compounds from 1-aryl-3,3-dimethyltriazenes and fluoride anions in acidic medium: 2. Synthesis of (S)[18F]-3-fluoro-a-methylphenylalanine. J Fluorine Chem, 107: 329-335, 2001.

32. Buruiana EC, Niculescu V, Buruiana T. Synthesis and properties of new polyurethane ionomers. I. Photosensitive cationomers with triazene units. J Appl Polym Sci, 88: 1203-1210, 2003.

33. Rachid Z, Katsoulas A, Brahimi F, Jean-Claude BJ. Synthesis of pyrimidinopyridine-triazene conjugates targeted to abl tyrosine kinase. Bioorg Med Chem Lett, 13: 3297-3300, 2003.

34. Kumar A, Mukarjee SK, Bhattacharya SK. Synthesis of N3-4-substituted-aryl-N1-(alkyl/aryl)substituted aryl) triazene-n1-oxides as potential anticonvulsant agents. Pharmazie, 38:66-67, 1983.
35. Buruiana EC, Melinte V, Buruiana $T$, Lippert $T$, Yoshikawa H, Mashuhara H. Synthesis and characterization of new hard polyurethanes with triazene pendants. J Photochem Photobiol A Chem, 171:261-267, 2005.

36. Buruiana EC, Niculescu V, Buruiana T. New polyurethane cationemers with naphthyl and phenyltriazene pendants:synthesis and properties J Appl Polym Sci, 92:2599-2605, 2004.

37. Kaupp G, Herrmann A, Schmeyers J. Waste-free chemistry of diazonium salts and benign separation of coupling products in solid salt reactions. Chem Eur J, 8:1395-1406, 2002.

38. Masoud MS, Ali AE, Shaker MA, Ghani MA. Solvent and substituent effects on spectroscopical changes of some diazoaminobenzene derivatives. Spectrochim Acta A Mol Biomol Spectrosc, 61: 3102-3107, 2005.

39. Dabbagh HA, Teimouri A, Chermahini AN, Shiasi R. DFT and ab initio calculations of the vibrational frequencies and visible spectra of triazenes derived from cyclic amines. Spectrochim Acta A Mol Biomol Spectrosc, 67: 437-443, 2007.

40. Prikryl J, Černý $M$, Bĕlohlavová $H$, Macháček V, Lyčka A. Structure of azo coupling products of 5-nitro-2,1-benzisothiazole-3-diazonium hydrogensulphate with aromatic amines. Dyes and Pigments, 72:392-402, 2007.

41. Ding W, Liu B, Vought JL, Yamauchi H, Lind SE Anticancer activity of the antibiotic clioquinol. Cancer Res, 65:3389-3395, 2005. 